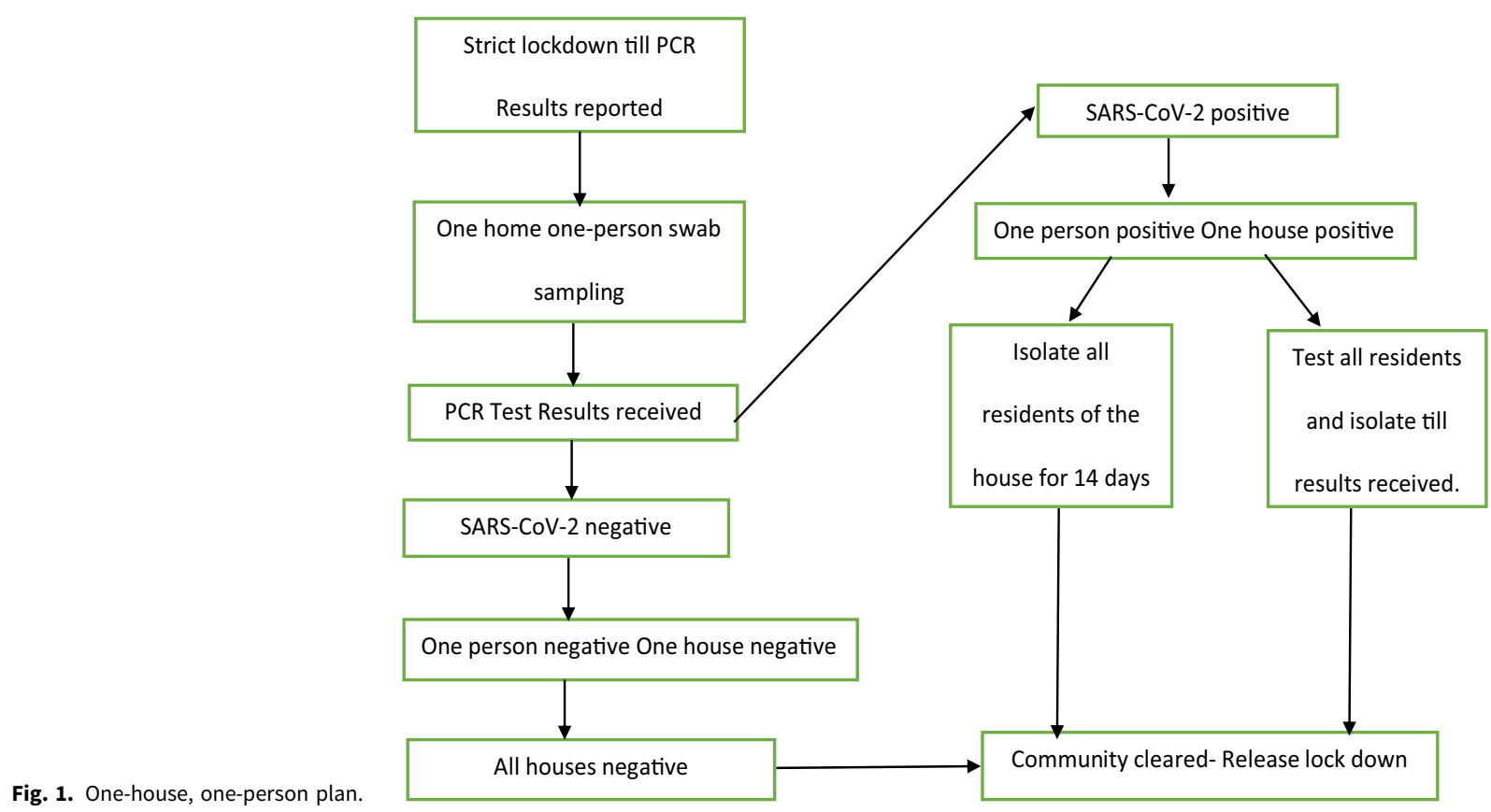

\section{References}

1. Quilty BJ, Clifford S, Flasche S, et al. Effectiveness of airport screening at detecting travellers infected with novel coronavirus (2019-nCoV). Euro Surveill 2020;25(5). doi: 10.2807/1560-7917.ES.2020.25.5.2000080.

2. Peto J. Covid-19 mass testing facilities could end the epidemic rapidly. BMJ 2020;368:m1163. doi: 10.1136/bmj.m1163.

3. Pakistan, G.o., International cases details. Internet, 2020.

4. Jiang XL, et al. Transmission potential of asymptomatic and paucisymptomatic SARS-CoV-2 infections: a three-family cluster study in China. J Infect Dis 2020 Apr 22 [Epub ahead of print]. doi: 10.1093/infdis/jiaa206.

5. Ye F, Zhang XL, Zhao XN, et al. Delivery of infection from asymptomatic carriers of COVID-19 in a familial cluster. Int J Infect Dis 2020.
6. Zhang J, Tian S, Lou J, Chen Y. Familial cluster of COVID-19 infection from an asymptomatic. Crit Care 2020;24(1):119.

7. Qian G, Yang N, Ma AHY, et al. A COVID-19 transmission within a family cluster by presymptomatic infectors in China. Clin Infect Dis 2020 Mar 23 [Epub ahead of print]. doi: 10.1093/cid/ciaa316.

8. Li P, Fu JB, Li KF, et al. Transmission of COVID-19 in the terminal stage of incubation period: a familial cluster. Int J Infect Dis 2020 Mar 16 [Epub ahead of print]. doi: 10.1016/j.ijid.2020.03.027.

9. Guan Q, Liu M, Zhuang YJ, et al. Epidemiological investigation of a family clustering of COVID-19 [in Chinese]. Zhonghua Liu Xing Bing Xue Za Zhi 2020;41:629-633.

\title{
Angiotensin-converting-enzyme inhibitors (ACE inhibitors) and angiotensin II receptor blocker (ARB) use in COVID-19 prevention or treatment: A paradox
}

\author{
Shaghayegh Haghjooy Javanmard ${ }^{1}$, Kiyan Heshmat-Ghahdarijani ${ }^{2}$ and Golnaz Vaseghi PhD, PharmD ${ }^{3}$ \\ ${ }^{1}$ Applied Physiology Research Center, Cardiovascular Research Institute, Isfahan University of Medical Sciences, Isfahan, Iran, ${ }^{2}$ Heart Failure Research Center, \\ Cardiovascular Research Institute, Isfahan University of Medical Sciences, Isfahan, Iran and ${ }^{3}$ Isfahan Cardiovascular Research Center, Cardiovascular Research \\ Institute, Isfahan University of Medical Sciences, Isfahan, Iran
}

To the Editor-Coronavirus disease 2019 (COVID-19), which affects type II alveolar cells of the human lung, is caused by severe acute respiratory syndrome coronavirus 2 (SARS-CoV-2). ${ }^{1}$ This virus was identified in December 2019 in Wuhan, China, for the

Author for correspondence: Golnaz Vaseghi, Email: golnazvaseghi@yahoo.com Cite this article: Javanmard SH, Heshmat-Ghahdarijani K, and Vaseghi G. (2021). Angiotensin-converting-enzyme inhibitors (ACE inhibitors) and angiotensin II receptor blocker (ARB) use in COVID-19 prevention or treatment: A paradox. Infection Control \& Hospital Epidemiology, 42: 118-119, https://doi.org/10.1017/ice.2020.195 first time ${ }^{2}$ and has spread all over the world, leading to a global pandemic. ${ }^{3}$

Renin-angiotensin system (RAS) signaling and angiotensinconverting enzyme 2 (ACE2) have been implicated in the pathogenesis of COVID-19. ${ }^{4}$ The virus binds to its target cells through angiotensin-converting enzyme 2 (ACE2), which is found in the type II alveolar cells of the lungs. Furthermore, ACE2 receptors are expressed in many extrapulmonary tissues such as heart, kidney, testis, endothelia, and the gastrointestinal tract. ${ }^{5,6}$ 
ACE2-expressing alveolar cells are also involved in the viral genome replication process. ${ }^{7}$

ACE2 degrades angiotensin (ANG) I to angiotensin (1-9), which is a ligand for angiotensin II receptor type $2\left(\mathrm{AT}_{2}\right)$. ANG (1-9) has regenerative and anti-inflammatory effects through its binding to the $\mathrm{AT}_{2}$ receptor. ${ }^{8}$ Moreover, ACE2 converts angiotensin II to angiotensin (1-7). ${ }^{9}$ ANG (1-7), through binding to the Mas receptor (MasR), mediates anti-inflammatory and vasodilatory effects and reduces reactive oxygen species (ROS). Thus, it counteracts the vasoconstriction and proinflammatory effects of ANG II. ${ }^{10,11}$ In addition, ANG (1-7) may prevent lung injury because of its vasodilator effect. ${ }^{12}$

Importantly, SARS-CoV infections and SARS spike protein downregulate ACE2 expression. ${ }^{13}$ Furthermore, blocking the RAS pathway deteriorated acute lung injury induced by the injection of SARS-CoV spike protein in mice. Thus, in contrast to most other coronaviruses, SARS-CoV may have become highly lethal because the virus dysregulates a lung protective pathway. $^{14}$

Animal studies have shown that ACE2 protects murine lungs from acute lung injury as well as reconciles SARS spike protein lung injury, suggesting a dual role of ACE2 in both SARS infections and protection from ARDS. ${ }^{12}$ The effect of ACE inhibitors (ACE-I) and angiotensin II type-I receptor blockers (ARBs) in the treatment and prevention of COVID-19 is not well recognized.

ACE-I and ARBs have been shown to upregulate the expression of ACE-2 or to prevent the loss of ACE2 in the heart; they may have a similar effect in lung tissue. ${ }^{15,16}$ Thus, an ACE-I and ARB blocker prescription in COVID-19 patient may make the patient vulnerable due to additional virus entrance and replication in type II alveolar cells.

Hypertension, diabetes, and coronary heart disease were the most common comorbidities associated with death from COVID-19 in Wuhan patients, ${ }^{17}$ which leads us to 2 paradoxical hypotheses:

1. The expression of ACE2 in hypertensive patients and patients with type 1 or type 2 diabetes, who are treated with ACE inhibitors ARBs, is increased. ${ }^{18}$ This upregulation may make these patients more vulnerable.

2. On the other hand, diabetes and hypertension are associated with decreased baseline levels of ACE2 expression. ${ }^{18}$ Therefore, SARS-CoV-2 binding to ACE2 may decrease residual ACE2 activity and lead to a predominance of ANG II through AT1 receptor signaling. In this case, ANG II causes pulmonary vasoconstriction and inflammatory and oxidative organ damage, ultimately progressing toward ARDS. ${ }^{19}$

Although some beneficial experimental evidence has emerged regarding ACEI or ARBs, and their use is well tolerated, inexpensive, and widespread; the potential therapeutic effects of these drugs in ARDS caused by SARS-CoV-2 is doubtful.

However, multiple regulatory associations have recommended that hypertensive COVID-19 patients do not stop taking their previosuly prescribed ACE inhibitors or ARBs. ${ }^{20}$ The evidence offered here precedes any clinical trials, and the paradoxical role of the aforementioned drugs should be solved in preclinical and epidemiological studies.

\section{References}

1. Zhu N, Zhang D, Wang W, et al. A novel coronavirus from patients with pneumonia in China, 2019. N Engl J Med 2020;382:727-733.

2. Lu H, Stratton CW, Tang Y. Outbreak of pneumonia of unknown etiology in Wuhan, China: the mystery and the miracle. J Med Virol 2020;92:401-402.

3. Whitworth J. COVID-19: a fast evolving pandemic. Trans $R$ Soc Trop Med Hyg 2020 Mar 21 [Epub ahead of print]. doi: 10.1093/trstmh/traa025.

4. Del Rio C, Malani PN. COVID-19-new insights on a rapidly changing epidemic. JAMA 2020 Feb 28 [Epub ahead of print]. doi: 10.1001/jama.2020.3072.

5. Lu R, Zhao X, Li J, et al. Genomic characterisation and epidemiology of 2019 novel coronavirus: implications for virus origins and receptor binding. Lancet 2020;395:565-574.

6. Wan Y, Shang J, Graham R, Baric RS, Li F. Receptor recognition by the novel coronavirus from Wuhan: an analysis based on decade-long structural studies of SARS coronavirus. J Virol 2020;94(7): pii: e00127-20.

7. Zhao Y, Zhao Z, Wang Y, et al. Single-cell RNA expression profiling of ACE2, the putative receptor of Wuhan COVID-19. bioRxiv 2020 [Epub ahead of print]. doi: 10.1101/2020.01.26.919985

8. Zambelli V, Bellani G, Borsa R, et al. Angiotensin-(1-7) improves oxygenation, while reducing cellular infiltrate and fibrosis in experimental acute respiratory distress syndrome. Intens Care Med Exper 2015;3(1):8.

9. Donoghue M, Hsieh F, Baronas E, et al. A novel angiotensin-converting enzyme-related carboxypeptidase (ACE2) converts angiotensin I to angiotensin 1-9. Circ Res 2000;87(5):E1-E9.

10. Tikellis C, Thomas MC. Angiotensin-converting enzyme 2 (ACE2) is a key modulator of the renin angiotensin system in health and disease. Int J Pept 2012;2012:256294.

11. Simões e Silva AC, Silveira KD, Ferreira AJ, Teixeira MM. ACE2, angiotensin-(1-7) and Mas receptor axis in inflammation and fibrosis. Br J Pharmacol 2013;169:477-492.

12. Imai Y, Kuba K, Rao S, et al. Angiotensin-converting enzyme 2 protects from severe acute lung failure. Nature 2005;436(7047):112-116.

13. Kuba K, Imai $Y$, Rao S, et al. A crucial role of angiotensinconverting enzyme 2 (ACE2) in SARS coronavirus-induced lung injury. Nat Med 2005;11: 875-879.

14. Reddy R, Asante I, Liu S, et al. Circulating angiotensin peptides levels in acute respiratory distress syndrome correlate with clinical outcomes: a pilot study. PLoS One 2019;14(3):e0213096.

15. Ocaranza MP, Godoy I, Jalil JE, et al. Enalapril attenuates downregulation of Angiotensin-converting enzyme 2 in the late phase of ventricular dysfunction in myocardial infarcted rat. Hypertension 2006;48:572-578.

16. Ferrario CM, Jessup J, Chappell MC, et al. Effect of angiotensin-converting enzyme inhibition and angiotensin II receptor blockers on cardiac angiotensin-converting enzyme 2. Circulation 2005;111:2605-2610.

17. Zhou F, Yu T, Du R, et al. Clinical course and risk factors for mortality of adult inpatients with COVID-19 in Wuhan, China: a retrospective cohort study. Lancet 2020;395:1054-1062.

18. Li, X, Zhang J, Zhuo J. The vasoprotective axes of the renin-angiotensin system: physiological relevance and therapeutic implications in cardiovascular, hypertensive and kidney diseases. Pharmacol Res 2017;125(Pt A):21-38.

19. Zhang H, Baker A. Recombinant human ACE2: acing out angiotensin II in ARDS therapy. Crit Care 2017;21:305.

20. Position statement of the ESC council on hypertension on ACE inhibitors and angiotensin receptor blockers. European Society of Cardiology website. https://www.escardio.org/Councils/Council-on-Hypertension-(CHT)/News/ position-statement-of-the-esc-council-on-hypertension-on-ace-inhibitors-andang. Published March 13, 2020. Accessed May 4, 2020. 